\title{
Contemporary Temperature Changes at the Ground Surface and in the Troposphere Over Vojvodina, Serbia
}

\author{
Vladan Ducić', Stevan Savićc ${ }^{2}$ Jelena Lukovićc ${ }^{1 *}$ \\ Received: January 2008 | Revised: November 2008 | Accepted: November 2008
}

\begin{abstract}
In this paper the near surface and tropospheric temperature trends are compared on the territory of Vojvodina were investigated, on the basis of four sets of data from ground-based and satellite observation, for the period 1979-2005. The trend analysis has shown that there is no amplification of trend of air temperature increase with altitude. On the basis of our calculations, we obtained the results that the air temperature increase in Vojvodina, approximately 1.5 times higher in the near-surface layer, compared to lower and middle layers of troposphere. This shows flat or decreasing amplification with altitude, in contrary to some models.
\end{abstract}

Key words: observed climate change, temperature, tropospheric temperature, linear trend, Vojvodina, Serbia.

\section{Introduction}

The problem of global air temperature changes has been the priority issue of scientists and professionals in the field. Significant number of papers has been written with various solution proposals to the problem (Mears et al., 2003; Vinnikov, Grody, 2003; Christy, Norris, 2004; Vinnikov et al., 2006; Radovanović et al., 2006). Intergovernmental Panel on Climate Change (IPCC, 2007) supports the notion that the major cause of air temperature increase in the late $2 \mathrm{O}^{\text {th }}$ century is the anthropogenic factor, i.e. the increase of $\mathrm{CO}_{2}$ concentration in the atmosphere (http://ipcc-wg1.ucar.edu/ wg1/wg1-report.html).

On the other hand, some authors argue the domination of natural factors in contemporary variability of the climate system. For example, Robock emphasises that "the research on the prospective influence of human-induced greenhouse effect needs to be interrelated with the study of external natural climatic factors (volcanic eruptions, changes in the solar activity), which stay constant, as well as internal dynamics of the climate system" (Robock, 2002).

\section{Data and methodology}

For the analysis of air temperature changes on the territory of Vojvodina, the temperature data series for the period 1979-2005 from the network of meteorological stations
(Palić, Sombor, Rimski Šančevi, Kikinda, Zrenjanin, Vršac, Sremska Mitrovica) (figure 1), were collected to be compared with the satellite measurements. Shown values of annual mean temperatures for seven meteorological stations were taken from Meteorological yearbooks of Republic Hydrometeorological Service of Serbia and Hydrometeorological Service of the Province of Vojvodina. However, inhomogeneity of data at meteorological stations in Serbia was detected (Smailagić and Jovanović, 1992), which demanded the data homogenization procedure first.

Homogeneity of mean annual air temperatures, measured at those 7 meteorological stations on the territory of Vojvodina, was tested by Alexandersson's test for shifts (Alexandersson, 1986). The test is based upon the assumption that the difference between temperature series at a candidate station (the one being tested) and the reference series is fairly constant in time. During the temperature series testing, the variations between candidate and reference station were used. Simultaneously, instead of the values obtained from meteorological stations, the successive increments of the data were used for calculations of square correlation coefficient $\left(\Delta \mathrm{T}=\mathrm{T}_{\mathrm{i}+1}-\mathrm{T}_{\mathrm{i}}\right)$, with the aim of minimizing the risk of making poor estimates of correlations between the candidate and reference temperature series because of the existing inhomogeneities (Peterson and Easter-

\footnotetext{
Faculty of Geography, University of Belgrade, Studentski trg 3/III, 11000 Belgrade, Serbia

2 Climatology and Hydrology Research Centre, Faculty of Science, University of Novi Sad, Trg Dositeja Obradovića 3, 21000 Novi Sad, Serbia * Corresponding author: Jelena Luković, e-mail: jelenalu@yahoo.com; Co-authors: vladan@gef.ac.yu (Vladan Ducić); stevan.savic@ig.ns.ac.yu (Stevan Savić)
} 


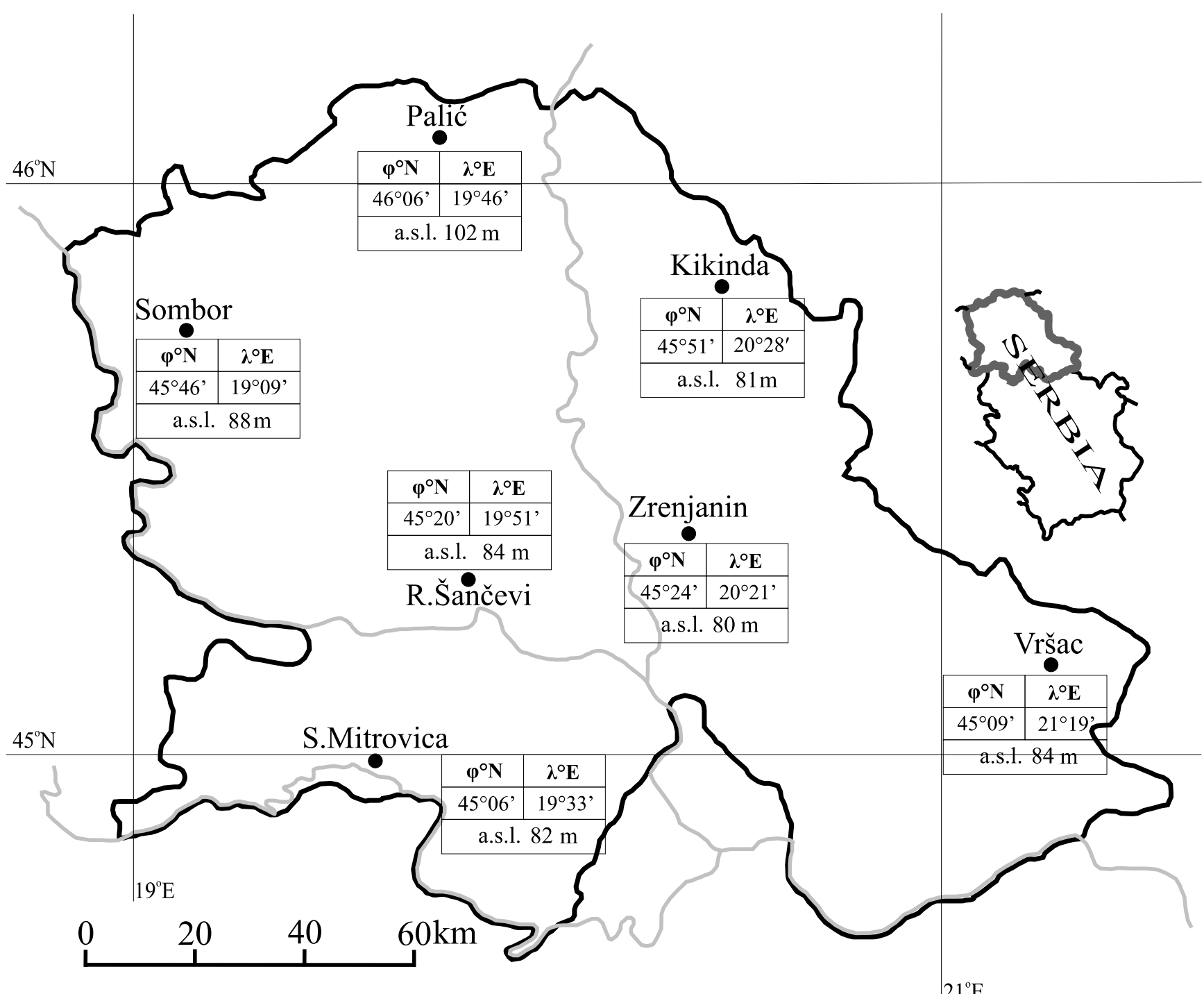

Figure 1 Positions of meteorological stations in Vojvodina and their geographical coordinates

ling, 1994). Between 2 and 5 stations were used for reference series. Correlation coefficient was above 0.9 in all cases.

During the testing process of mean annual temperature series, the results showed that at 6 meteorological stations the temperature series were homogenous. The homogeneity break point which exceeds the minimum threshold level of importance $\alpha=0.05$ (the value is 7.643) (Khaliq and Ouarda, 2007), was recorded at Rimski Šančevi station, and the break point year was 1990. After performing series of several homogeneity adjustments (Moberg and Alexandersson, 1997), the mean annual air temperatures at Rimski Šančevi station were homogenised.

Mean value for homogenised series at all seven meteorological stations (MSV) was used in the analysis of contemporary air temperature changes on the territory of Vojvodina.

Besides this set of data, the air temperature series were also analysed from $\mathrm{GHCN}^{3}$ and $\mathrm{HadCRUT}_{3}{ }^{4}$. The data obtained from GHCN are the result of ground-based meteorological observations around the world, comprising also the observations from this area. The data are available (http:// www.co2science.org/scripts/CO2ScienceB $2 \mathrm{C} /$ data/temper-

3 GHCN-Global Historical Climatology Network

4 Hadley Centre and the Climatic Research Unit at the University of East Anglia atures/ghcn.jsp) for the period since 1880 as grids $5^{\circ} \times 5^{\circ}$ latitude and longitude. It is essential to this point to remark that the distribution of meteorological stations over a grid square varies; however, it can be eliminated by certain statistical tools. Thus, their comparison is enabled.

HadCRUT3 $_{3}$ is a network of data from ground-based instrumental measurements which are expressed as temperature anomalies from mean values. The data are available (http://www.co2science.org/scripts/CO2ScienceB2C/data/ temperatures/hadley.jsp) in the form of mean annual values for the period since 1880 and organized in grids $5^{\circ} \times 5^{\circ}$. This database is the result of cooperation between Met Office Hadley Centre and Climatic Research Unit at the University of East Anglia.

Ground-based measurements demonstrate objective deficiencies. First, the measurements cover only certain spots of the areas, the spots where meteorological stations are situated, but not the research area. Second, frequently at those "spots" the phenomenon of urban heat island occurs, which is significantly warmer than its surroundings. Thus, the fake illustration of higher temperature values for the broader area is formed.

With regards to objective deficiencies of ground-based measurements which further reflect in the temperature 
trend, we have decided to include the series from satellite observations. Despite the relatively short period of measurements, satellite data offer reliable values deprived of local influences (e.g. urban heat island).

The data from satellite observations for the period between 1979 and 2005 were used in the research. Satellite data obtained from NASA were processed at the University of Alabama in Huntsville(UAHMSU)(http://www.co2science.org/scripts/CO2ScienceB2 $\mathrm{C} /$ data/temperatures/ msu.jsp). Opposite to the ground-based observations data at GHCN, these data refer to the $8 \mathrm{~km}$ thick bottom layer of the atmosphere. As far as the covered area is concerned, these data are global and available in the form of grids $2.5^{\circ} \times 2.5^{\circ}$ latitude and longitude. The time framework for the data is set to the beginning of satellite observations in 1979 (Christy et al., 2000).

Additionally, there are Remote Sensing Systems (RSS) the network of satellite data in Santa Rosa, California. These data are available as a geographical belt (from $-70^{\circ} \mathrm{S}$ to $82.5^{\circ} \mathrm{N}$ ), unfortunately not in the form of grids, therefore they were not used in the calculations of regional trends. Our calculated correlation coefficient for those two sets of satellite data (UAHMSU and RSS) for the belt $70^{\circ} \mathrm{S}$ to $82.5^{\circ} \mathrm{N}$, for the series 1979-2005, had the values of 0.98 , indicating the high correspondence of the two series. However, there is the difference between the values of linear trend which is the result of data processing dissimilarity. Concerning the fact that GHCN, MSU and HadCRUT3 are given as anomalies with reference to period from 1979 up to 1998, MSV data are also averaged using the same period.

Methodologically, the commonly mathematical-statistical methods (trend analysis, correlation coefficient, standard deviation) were used in the paper.

\section{Results and discussion}

Parallel data for different networks and satellite measurements were given in the Table 1 . According to the resolution of available data, the coordinates $15-25^{\circ} \mathrm{E}$ and $45-50^{\circ} \mathrm{N}$ were chosen, within which the larger portion of Vojvodina is situated. High resolution of satellite data enabled the observation of grid at $2.5^{\circ} \times 2.5^{\circ}$, i.e. in this case coordinates $17.5^{-}$ $22.5^{\circ} \mathrm{E}$ and $45-47.5^{\circ} \mathrm{N}$.

Correlation coefficient (R) between HadCRUT3 and GHCN for the period 1979-2005 is 0.99. Homogenised ground-based air temperature series for Vojvodina (MSV) show the same correlation coefficient of 0.98 for both HadCRUT3 and GHCN. Firstly, it indicates that there is no major discrepancy between HadCRUT3 and GHCN. On the other hand, it justifies the procedure of data homogenisation for Vojvodina. In spite of some remained quality problems the used time series are suitable for examining climatic variability. In case of near surface data the very high correlations is a strong evidence for that.

However, correlation coefficients between ground and satellite measurements are relatively low. Thus, $\mathrm{R}$ between MSV and satellite data of high resolution 17.5-22.5 $\mathrm{E}$ and $45-47.5^{\circ} \mathrm{N}$ is 0.21 , whereas similar values of $\mathrm{R}$ are calculated between HadCRUT3 (o.16) and GHCN (o.20) with satellite data. Such value discrepancies of $\mathrm{R}$ could be explained by the fact that air temperature data refer to different alti- tudes. Ground measurements record the air temperature at $2 \mathrm{~m}$ height, whereas satellite data refer to the first $8 \mathrm{~km}$ layer of troposphere. It is important to add that Johanson and $\mathrm{Fu}$ (2006) have estimated the maximal error of calculat ed trends to be $0.01^{\circ} \mathrm{K} /$ decade. Also, the physical relevance of estimated linear trends is affected by natural noise and low frequency changes (Mills, 2006). This corruption is the highest when the time series are short, as in our case.

All three groups of ground-based measurements record minimum values in 1980 , with the highest deviation recorded by MSV $\left(-1.21^{\circ} \mathrm{C}\right)$. Similarly, all ground measurements record maximum values for 2000 , but the deviations are smaller, ranging from $1.73^{\circ} \mathrm{C}$ for $\mathrm{GHCN}$ to $1.99^{\circ} \mathrm{C}$ for MSV.

Satellite measurements for both resolutions recorded the largest negative deviation in $1982\left(-1.05^{\circ} \mathrm{C}\right.$ for $15-25^{\circ} \mathrm{E}$ and $45-50^{\circ} \mathrm{N},-1.12^{\circ} \mathrm{C}$ for $17.5-22.5^{\circ} \mathrm{E}$ and $\left.45-47.5^{\circ} \mathrm{N}\right)$. Maximum deviation was recorded in 1987 (ranging from $1.14^{\circ} \mathrm{C}$ from the first network to $1.05^{\circ} \mathrm{C}$ for the second).

Comparative analysis of linear trend values has shown the highest increase within MSV (0.0427 $\mathrm{C}$ annually) (Fig ure 2). Slightly smaller values were observed within trends for GHCN (0.0384 ${ }^{\circ} \mathrm{C}$ annually) and HadCRUT3 (0.0398 ${ }^{\circ} \mathrm{C}$ annually). Explicitly, all three values of the ground-based measurements trend are approximately similar and comparable. Compared to air temperature trends in Europe (annually $\mathrm{GHCN} 0.039^{\circ} \mathrm{C}$ and $\mathrm{HadCRUT}_{3} 0.040^{\circ} \mathrm{C}$ ), the air temperature changes in Vojvodina are similar. However, the changes are higher than the global ones (annually GHCN $0.026^{\circ} \mathrm{C}$ and HadCRUT3 $0.020^{\circ} \mathrm{C}$ ). Relatively fast warming in Vojvodina can be a sign of sensitivity demonstrated by GCM scenarios (Tebaldi et al., 2005).

The data on the linear trend for the first layer of troposphere at altitude of $8 \mathrm{~km}$ based on satellite observations show lower values compared to data of ground observations. Thus, the trend of satellite data of low resolution is $0.0275^{\circ} \mathrm{C}$ annually, whereas the one for the high resolution $\left(17.5-22.5^{\circ} \mathrm{E}\right.$ and $45-47.5^{\circ} \mathrm{N}$ ) is $0.0288^{\circ} \mathrm{C}$ annually. Both values are indisputably lower compared to those obtained by ground measurements in all three networks. Compared to the data for $\mathrm{Eu}-$ rope $\left(0.030^{\circ} \mathrm{C}\right)$, the linear trend of air temperature changes in Vojvodina is slightly smaller. Considering the global level, the satellite data indicate a minor change $\left(0.013^{\circ} \mathrm{C}\right)$. It is also essential to remark that all calculated values of the linear trend of air temperature statistically significant with $0.05-$ 0.025 risk of first type error in hypothesis testing.

Apparently, there is a discrepancy in the trend of air temperature increase between the satellite and ground measurements. The discrepancy was higher prior to the corrections being made. Those corrections have been done 2005 due to methodological processing (Maers and Wentz, 2005). Explic itly, UAHMSU measurements recorded lower values of global temperature trend up to $2005\left(0.07^{\circ} \mathrm{C}\right)$. After the corrections had been made in data processing, the discrepancy was lowered, but remained noticeable. Moreover, there were discrepancies between the satellite data themselves, i.e. their processing. On the basis of RSS data for the period 1979-2005, the trend value ${ }^{6}$ was $0.19^{\circ} \mathrm{C}$ per a decade (http://www.ssmi.com/

\footnotetext{
Between $35-70^{\circ} \mathrm{N}$ and $-10-45^{\circ} \mathrm{E}$

6 However, certain corrections were made at the beginning of 2008, and RSS trend value is almost equal to MSU
} 
Table 1 Air temperature anomalies (averaged from 1979 through 1998) for different networks in Vojvodina

\begin{tabular}{|c|c|c|c|c|c|}
\hline Years & $\begin{array}{c}\text { GHCN } \\
15-25^{\circ} \mathrm{E} \\
45-50^{\circ} \mathrm{N}\end{array}$ & $\begin{array}{c}\text { HADCRUT3 } \\
15-25^{\circ} \mathrm{E} \\
45-50^{\circ} \mathrm{N}\end{array}$ & $\begin{array}{c}\text { MSU } \\
15-25^{\circ} \mathrm{E} \\
45-50^{\circ} \mathrm{N}\end{array}$ & $\begin{array}{c}\text { MSU } \\
17.5-22.5^{\circ} \mathrm{E} \\
45-47.5^{\circ} \mathrm{N}\end{array}$ & MSV \\
\hline 1979 & 0.25 & 0.23 & -0.37 & -0.35 & 0.24 \\
\hline 1980 & -0.96 & -1.03 & 0.06 & 0.01 & -1.21 \\
\hline 1981 & 0.11 & 0.20 & 0.33 & 0.35 & -0.08 \\
\hline 1982 & 0.39 & 0.25 & -1.05 & -1.12 & 0.09 \\
\hline 1983 & 0.75 & 0.77 & -0.48 & -0.46 & 0.40 \\
\hline 1984 & -0.15 & -0.17 & -0.75 & -0.71 & -0.40 \\
\hline 1985 & -0.81 & -0.87 & -0.89 & -0.84 & -1.02 \\
\hline 1986 & -0.04 & -0.08 & 0.51 & 0.50 & -0.35 \\
\hline 1987 & -0.53 & -0.43 & 1.14 & 1.05 & -0.48 \\
\hline 1988 & 0.19 & 0.37 & 0.77 & 0.81 & 0.12 \\
\hline 1989 & 0.89 & 0.81 & -0.12 & -0.14 & 0.45 \\
\hline 1990 & 0.97 & 0.95 & 0.12 & 0.23 & 0.79 \\
\hline 1991 & -0.13 & -0.10 & 0.35 & 0.34 & -0.65 \\
\hline 1992 & 0.95 & 1.00 & 0.78 & 0.85 & 0.99 \\
\hline 1993 & 0.06 & 0.26 & -0.48 & -0.73 & -0.02 \\
\hline 1994 & 1.64 & 1.67 & 0.04 & -0.01 & 1.42 \\
\hline 1995 & 0.42 & 0.48 & 0.01 & 0.04 & 0.15 \\
\hline 1996 & -0.46 & -0.46 & -0.70 & -0.45 & -0.58 \\
\hline 1997 & -0.02 & 0.06 & 0.15 & 0.16 & -0.29 \\
\hline 1998 & 0.51 & 0.58 & 0.59 & 0.46 & 0.35 \\
\hline 1999 & 0.81 & 0.89 & 0.38 & 0.51 & 0.61 \\
\hline 2000 & 1.73 & 1.76 & 0.22 & 0.33 & 1.99 \\
\hline 2001 & 0.69 & 0.67 & 0.42 & 0.54 & 0.59 \\
\hline 2002 & 1.46 & 1.44 & -0.06 & -0.08 & 1.65 \\
\hline 2003 & 0.72 & 0.72 & 0.71 & 0.80 & 0.54 \\
\hline 2004 & 0.54 & 0.53 & 0.53 & 0.45 & 0.38 \\
\hline 2005 & 0.12 & 0.11 & 0.51 & 0.46 & -0.31 \\
\hline Average & 0.37 & 0.39 & 0.10 & 0.11 & 0.20 \\
\hline Standard deviation & 0.68 & 0.68 & 0.56 & 0.56 & 0.76 \\
\hline Linear trend & 0.0384 & 0.0398 & 0.0275 & 0.0288 & 0.0427 \\
\hline
\end{tabular}

$\mathrm{msu} / \mathrm{msu}$ _data_description.html\#msu_decadal_trends), whereas UAHMSU data show the value of $0.13^{\circ} \mathrm{C}$ per decade (http://vortex.nsstc.uah.edu/data/msu/t2lt/uahncdc.lt).

The researchers render dissimilar explanations of the divergence between satellite and ground measurements, which could be classified into three groups. The first group would comprise the errors in the measurement procedure; the second group would refer to various impacts of natural and anthropogenic factors on temperature at certain altitudes; and the third group would be base on the divergence in spatial distribution of observations (Santer et al., 2000). However, the divergences are inevitable reality (Douglass et al., 2004b). On the other hand, the analysis of radio sonde data in lower and middle layers of troposphere match the UAHMSU data, which supports the statement on the data reliability (http:// www.marshall.org/pdf/materials/415.pdf).

Considering the analysed data in the previous section, we attempted to test out whether the divergence in the trends possibly highlights the potential causes of climate change? The scientific papers list that under the dominating conditions of anthropogenic greenhouse effect; higher increase of air temperature should be expected in middle and lower layers of troposphere than in the near-surface layer (Santer et al., 2000; NRC, 2000; NAS, 2001; IPCC - http://ipcc-wg1. ucar.edu/wg1/wg1-report.html). The estimations stress the fact that the increase should be 1.2 to 1.5 times higher, depending on the latitude and applied model.

The data analysis of yearly trend divergence in air temperature between satellite data for grid $45-47.5^{\circ} \mathrm{N} 17.5-22.5^{\circ} \mathrm{E}$ and MSV (Figure 3 ) has shown the decreasing trend.

It complies with the fact that the increase trend of air temperature in lower layer is higher. The largest negative deviations were recorded in the last quarter of the observed period (2000 and 2002). The obtained results do not contribute to the hypothesis about altitude amplification of the increase trend of air temperature. Conversely, on the basis of our calculations, 


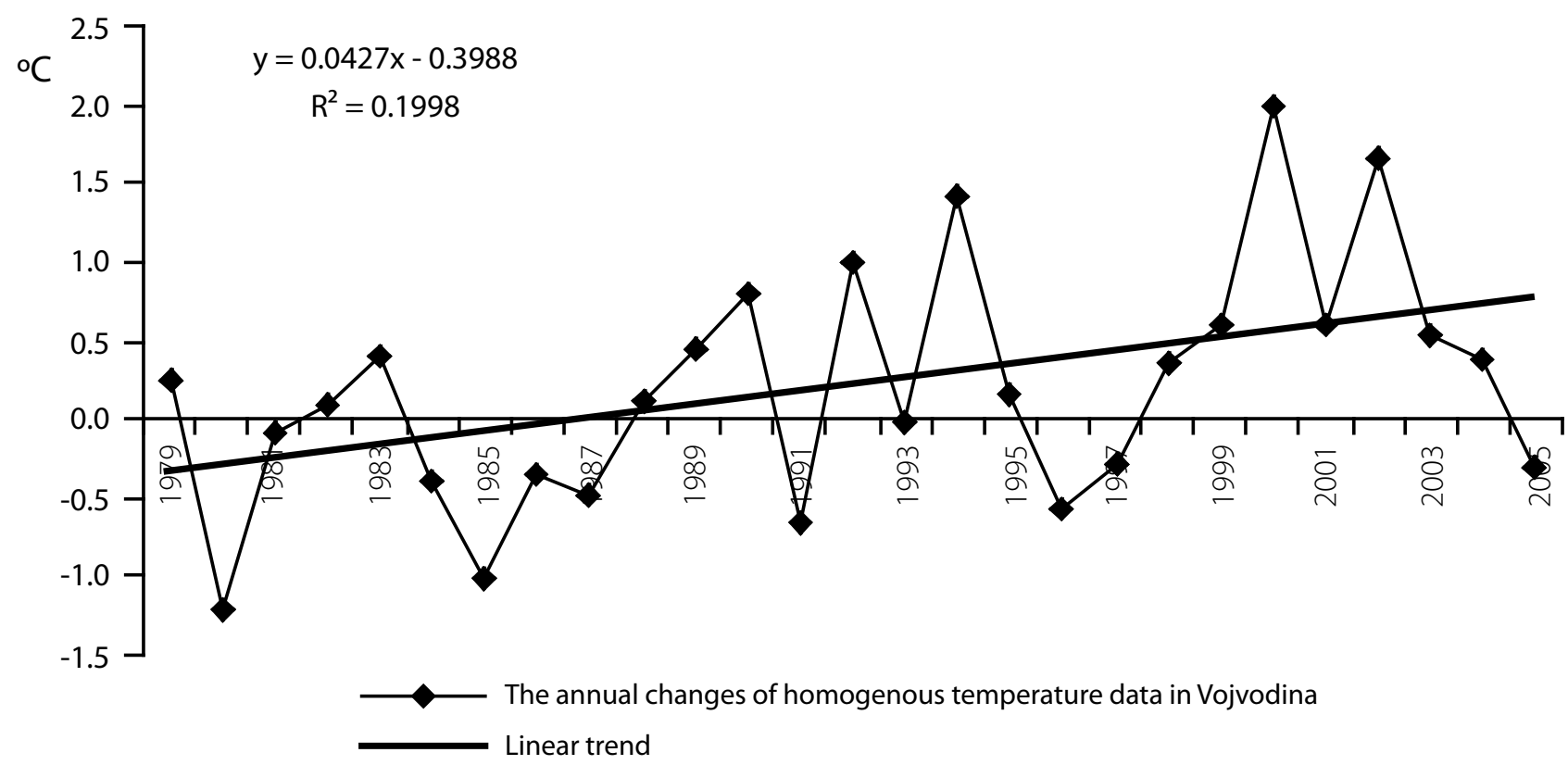

Figure 2 Annual change of homogenised air temperature data in Vojvodina

we obtained the results that the air temperature increase in Vojvodina, approximately 1.5 times higher in the near-surface layer, compared to lower and middle layers of troposphere.

A panel convened by the National Research Council (2000) found for the satellite era (since 1979) 'apparently conflicting surface and tropospheric temperature trends' that could not be reconciled, with the Earth's surface warming faster than the lower troposphere. The panel concluded, after considering possible systematic errors that 'substantial disparity remains.' From a study of several independent observational datasets (Douglass et al., 2004b) confirmed that the disparity was real and arose mostly in the tropical zone. Also, Douglass et al. (2004a) showed that three state-of-the-art General Circulation Models (GCMs) predicted a temperature trend that increased with altitude, reaching a maximum ratio to the surface trend ('amplification' factor $R$ ) as much as 1.5-2.0 at a pressure (altitude) about $200-400 \mathrm{hPa}$. This was in disagreement with observations, which showed flat or decreasing amplification factors with altitude.

Also the global data contribute to the conclusion. Namely, in the observed period, similar results are obtained. The trend value for ground-based measurements at $\mathrm{GHCN}$ is $0.026^{\circ} \mathrm{C}$ annually, whereas the trend value obtained at Had$\mathrm{CRUT}_{3}$ is $0.020^{\circ} \mathrm{C}$ annually. Both values are higher than the satellite obtained trend value for air temperature, which are $0.013^{\circ} \mathrm{C}$ and $0.019^{\circ} \mathrm{C}$ at UAHMSU and RSS, respectively.

\section{Conclusion}

The data on air temperature measurements within different observation networks over the territory of Vojvodina were processed in this paper. The first set comprises ground measurements within the global data network (GHCN and

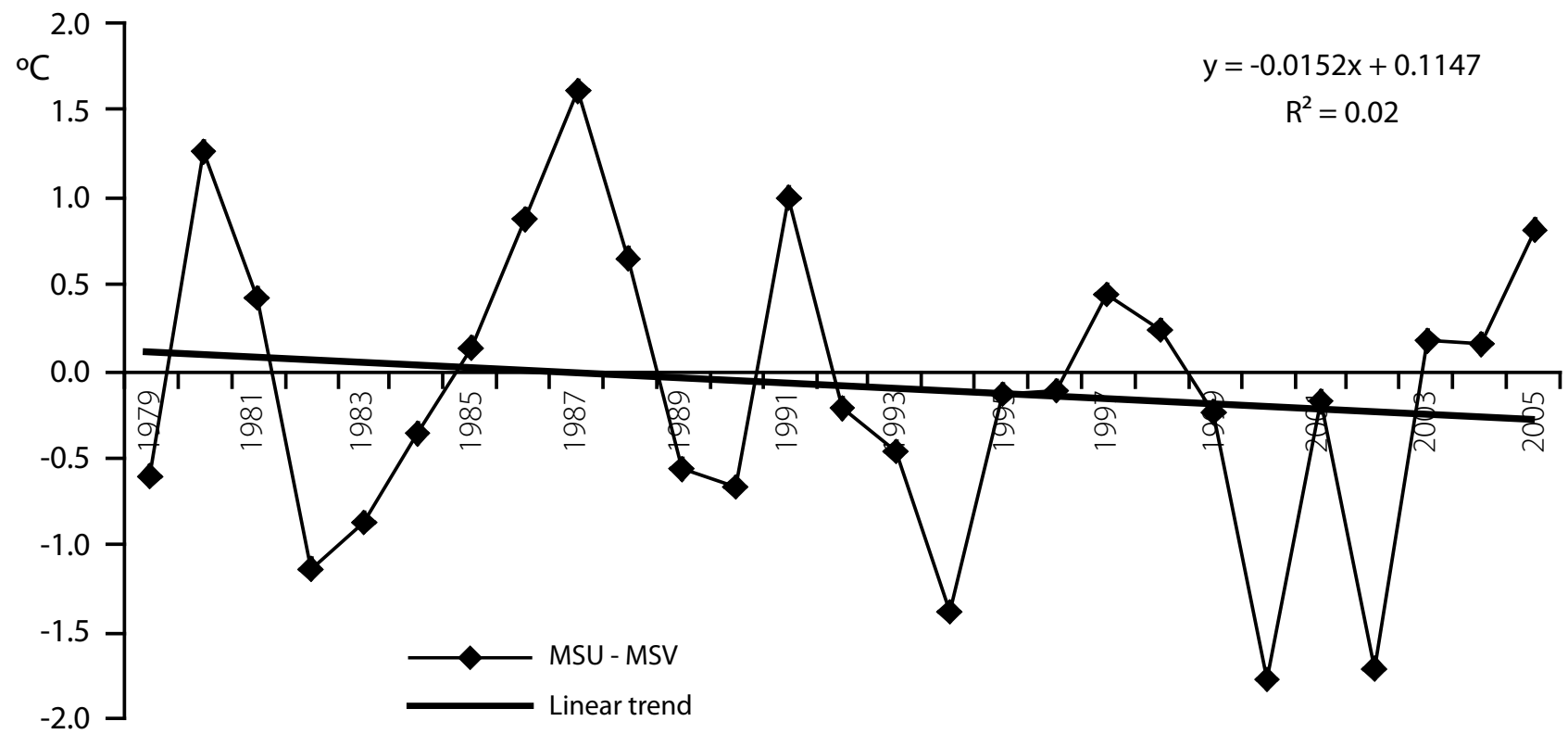

Figure 3 Air temperature differences between MSU and MSV data 
HadCRUT3) and at 7 meteorological stations in Vojvodina, for which homogenization was performed by Alexandersson's test. The second set of data comprises satellite observations in two resolutions.

The analysis of the data has shown the discrepancy in air temperature trend between ground and satellite measurements. Explicitly, the air temperature increase at the nearsurface layer has shown higher values $\left(\mathrm{GHCN} 0.0384^{\circ} \mathrm{C}\right.$ annually, HadCRUT3 $0.0398^{\circ} \mathrm{C}$ annually, homogenised data for Vojvodina - MSV $0.0425^{\circ} \mathrm{C}$ annually) compared to satellite observations (UAHMSU from $0.0275^{\circ} \mathrm{C}$ to $0.0288^{\circ} \mathrm{C}$ annually).

With reference to written resources it may be concluded that the variations in the air temperature trend between measurements made at lower and middle layers of troposphere and those made in the near-surface layer stand for physical reality. Besides, MSV data and satellite data may be considered reliable.

The obtained results show the lack of amplification in the increasing trend of air temperature both in Vojvodina and global one, for the period from 1979 to 2005.

\section{Acknowledgements}

This study is supported by the Serbian Ministry of Science under Grants 146005 and 146019. The authors would like to thank the anonymous referees for their encouraging comments.

\section{References}

Alexandersson, H. 1986. A homogeneity test applied to precipitation data. Journal of Climatology 6, 661-675.

Christy J.R., Spencer R.W., Braswell W.D. 2000. MSU Tropospheric Temperatures: Dataset Construction and Radiosonde Comparisons. Journal of Atmospheric and Oceanic Research 17, 1153-1170.

Christy J.R., Norris, W.B. 2004. What may we conclude about global tropospheric temperature trends? Geophysical Research Letters 31, Lo6211, doi:10.1029/2003GL019361.

Douglass D.H, Pearson B.D, Singer S.F. 2004a. Altitude dependence of atmospheric temperature trends: climate models versus observation. Geophysical Research Letters 31, L13208, DOI:10.1029/2004GL020103.

Douglass, D.H., Pearson B.D., Singer S.F., Knappenberger P.C., Michaels P.J. 2004b. Disparity of tropospheric and surface temperature trends: new evidence. Geophysical Research Letters 31, L13207, 1-5.

Intergovernmental Panel on Climate Change (2007), Climate Change (2007): The Scientific Basis. Contribution of Working Group 1 to the Fourth Assessment Report of the Intergovernmental Panel on Climate Change. Cambridge

Johanson, C.M., Fu, Q. 2006: Robustness of tropospheric temperature trends from MSU channels 2 and 4 . Journal Climate 19, 4234-4242.

Mills, T.C. 2006: Modelling current trends in northern hemisphere temperatures. International Journal of Climatology 26, 867-884.

Khaliq, M.N., Ouarda, T.B.M.J. 2007. On the critical values of the standard normal homogeneity test (SNHT). International Journal of Climatology 27, 681-687.
Mears C.A., Schabel, M.C., Wentz, F.J. 2003. A reanalysis of the MSU channel 2 tropospheric temperature record. Journal of Climatology 16, 3650-3664.

Mears, C.A., Wentz, F.J. 2005. The effect of diurnal correction on satellite-derived lower tropospheric temperature. Science 309, $1548-1551$.

Moberg, A., Alexandersson, H. 1997. Homogenization of Swedish temperature data. Part II: homogenized gredded air temperature compared with a subset of global gridded air temperature since 1861. International Journal of Climatology 17, 35-54.

NAS, 2001. Climate Change Science: An Analysis of Key Questions. National Academy of Sciences, National Academy Press, Washington DC, 1-42.

NRC, 200o. Reconciling Observations of Global Temperature Change. National Academy Press, Washington DC, $1-85$.

Peterson, T.C., Easterling, D.R. 1994. Creation of homogeneous composite climatological reference series. International Journal of Climatology 14, 671-679.

Radovanović, M., Vemić, M., Popović, I. 2006. Global Climate Changes - Antidogmatron. Geographica Pannonica $10,9-13$.

Robock, A. 2002. Volcanic eruptions. Encyclopedia of Global Environmental Change, vol. 1, Ted Munn, Ed., (John Wiley and Sons, London), 738-744.

Santer, B.D., Wigley, T.M.L., Gaffen, D.J., Bengtsson, L., Doutriaux, C., Boyle, J.S., Esch, M., Hnilo, J.J., Jones, P.D., Meehl, G.A., Roeckner, E., Taylor, K.E., Wehner, M.F. 200o. Interpreting Differential Temperature Trends at Surface and in the Lower Troposphere. Science 287, 1227-1232.

Smailagić, J., Jovanović, O. 1992. Homogeneity of the annual air temperature and precipitation on the major meteorological stations in Serbia. Researches Review of the Hydrological and Meteorological Service of Serbia, Belgrade. (in Serbian)

Vinnikov, K.Y., Grody, N.C. 2003. Global warming trend of mean tropospheric temperature observed by satellites. Science 302, pp. 269- 272.

Vinnikov, K.Y., Grody, N.C., Robock, A., Stouffer, R.J., Jones, P.D., Goldberg, M.D. 2006. Temperature trends at the surface and in the troposphere. Journal of Geophysical Research 111, Do3106, doi:10.1029/2005JDoo6392.

Tebaldi, C., Smith, R.L., Nychka, D., Mearns, L.O. 2005. Quantifying uncertainty in projections of regional climate hange: A Bayesian approach to the analysis of multi model ensembles. Journal of Climate 18, 1524-1540.

http://ipcc-wg1.ucar.edu/wg1/wg1-report.html

http://www.co2science.org/scripts/CO2ScienceB2 $2 /$ data/ temperatures/ghcn.jsp

http://www.co2science.org/scripts/CO2ScienceB2C/data/ temperatures/hadley.jsp

http://www.co2science.org/scripts/CO2ScienceB2C/data/ temperatures/msu.jsp

http://www.ssmi.com/msu/msu_data_description. html\#msu_decadal_trends

http://vortex.nsstc.uah.edu/data/msu/t2lt/uahncdc.lt

http://www.marshall.org/pdf/materials/415.pdf

IPCC - http://ipcc-wg1.ucar.edu/wg1/wg1-report.html 